\title{
Revisions about Government Subsidy Disclosures and Investors' Response to Earnings Reports: Evidence from the 2017 Government Subsidy Disclosures
}

\author{
Xiaoyu $\mathrm{Hu}^{1}$, Jinying Tang $^{1}$ \& Qun Wang ${ }^{2}$ \\ ${ }^{1}$ School of Management, Jinan University, Guangzhou, China \\ ${ }^{2}$ School of Accounting, Tongling University, Anhui, China \\ Correspondence: Xiaoyu Hu, School of Management, Jinan University, Guangdong province, Guangzhou 510632, \\ China.
}

Received: June 27, 2019

Accepted: July 15, $2019 \quad$ Available online: July 26, 2019

doi:10.11114/afa.v5i2.4411

URL: https://doi.org/10.11114/afa.v5i2.4411

Foundations of College Students Innovation Projet in China (NO. CX2019432)

Foundations of Social Science Committee in China, Anhui province Higher Education Social Science Project (No. SK2019A0598)

\begin{abstract}
We examine whether the quality of information in earnings reports, as indicated by the earnings response coefficient (ERC) decreases when the measurement and disclosure of government subsidy has been changed by revising accounting standards. According to the old accounting standards in China, the gains from government subsidy should be reflected in "non-operating" income. However, the newly revised accounting standards regulates that a part of government subsidy can be reflected in the report item of "other income" in under the operating income item. We use 2017 revisions of accounting standards in China as an instrument to capture a change in the position of financial statements where the government subsidy is revealed. Employing a difference-in-differences design and exploiting the adoption of the new accounting standards, we find a statistically and economically significant decrease in ERC for treated firms relative to controlled firms. Our findings represent the first empirical evidence that the change of government disclosures can negatively affect the information content of earnings report.
\end{abstract}

Keywords: Earnings Response Coefficient (ERC), government subsidy, accounting standards

\section{Introduction}

\subsection{Introduce the Problem}

In order to standardize the confirmation, measurement and disclosure of government subsidies, the 2017 edition of Chinese accounting standards in terms of government subsidy has been revised. The difference between the old and new versions is as follows: in the presentation and disclosure, the new accounting standard allows a part of government subsidy to be incorporated into "other income", which is reflected in the "Operating profit" item. In contrast, in the old accounting standards, all the government subsidies received by the companies should be revealed in the "Non-operating Income" item. This shift may exerts a positive or negative impact on the information content of earnings report.

\subsection{Explore Importance of the Problem}

With the development of China's domestic capital market, the degree of transparence of information and the effectiveness of market have increased. The main purpose of the revision of accounting standards is to improve the quality of accounting information so that the content of earnings report provided by the enterprises can be more effective and thus accurately reflect the profitability as well as growth of companies. Although there are still some differences between Chinese financial report standards and International Financial Reporting Standards, there is a tendency of convergence through revisions in recent years. Thus, examining whether the revision has some influences on the content of earnings report and investors' response is important. According to International Financial Reporting Standards (IFRS), government subsidies related to income can be reflected in general item like "Other Income". So we can see that is allowed in newly revised Chinese 
accounting standards. To test the effects of this change can help us know how accounting standards affect the information environment of the capital market and change the habits of investors' decision-making judgements, which is beneficial for improving the efficiency of financial reporting standards.

\subsection{Describe Relevant Scholarship}

The information can be defined as a change in investors' expectations and their behaviors of making decisions in investment. According to valuation theory, the value of common stock is influenced by the earnings. Thus, the earnings report means a lot to investors. Miller and Modigliani indicates that if reported earnings are adjusted for measurement errors through the use of instrumental variables, the adjusted earnings can be used to predict the value of firm. But the prerequisite for this is that earnings do have information content. Beaver, W. H. (1968) empirically examined the extent to which the common stock investors perceive earnings to possess informational values, which directed its attention to investor reaction to earnings announcement and concluded that investors do react to earnings. The information content of earnings can be reflected as earnings response coefficient (ERC), which is measured by the investors' reaction to unexpected earnings. There are many factors accounting for the change of information content. One of the important factors is the change of accounting rules. Findings suggest that information content increased in 16 countries that mandated IFRS relative to 11 that maintained domestic accounting standards with several mechanism such as reducing reporting lag, increasing analyst following and increasing foreign invest. (Landsman, W. R., Maydew, E. L. \& Thornock, J. R, 2012).

Previous studies have found that the mispricing and market inefficiency in the capital market are often caused by factors such as investor's cognitive bias, corporate earnings management behavior and information disclosure behavior. Much research have proved that individuals tend to have the habit of accounting fixation. Dearman and Shield (2005) used experimental research methods to demonstrate the cognitive behavioral bias of investors - the "function lock" phenomenon. The study found that investors' accounting knowledge, problem-solving skills, and the inherent motivation to participate in decision-making can influence cognitive processes. Because of the "function lock", the investor might be more sensitive to some items in the earnings announcement especially when they contain some noise. Landsman, W. R., Maydew, E. L. \& Thornock, J. R (2012) all pointed out that the design of accounting standards itself, the system of standard implementation, etc. will affect the performance of accounting standards. Therefore, vigorously promoting the improvement of the accounting system will help reduce the mispricing caused by the "function lock-in" phenomenon. Conversely, if the accounting standards cannot be designed properly, it will cause a negative effect on the information content because of the "function lock".

From the manager's point of view, managers have many incentives for earnings management, such as dividends, debt contracts (Watts and Zimmerman, 1990) or attracting investors to invest in stocks, changing investors' understanding of the company's current value (Dechow et al., 1996). Thus, if accounting standards is not well designed, it may enable the managers to do earnings management more easily and thus reduce the information content of earnings report. Numerous research on accounting standards has confirmed that more stringent accounting regulations can reduce managers' earnings management behavior and improve the quality of financial reporting information (Schipper, 2003; Ewert \& Wagenhofer, 2005). On the other hand, however, some studies show that the level of earnings management are likely to increase if it is placed on a foreign country's accounting standards (Igor Goncharov \& Jochen Zimmermann, 2006). Other Chinese studies also suggest that the new accounting standards in terms of government subsidy may cause more earnings management. According to the new accounting standards, government subsidies for commodities which are sold below the cost can be recognized as operating income; government subsidies obtained for purchasing with high price can be allowed for cost reduction. Apart from these two situations, if the government subsidies are related to the daily business activities, it can be reflected in the item of "Other income". This breaks through the old standard that the original government subsidies can only be included in "Non-Operating income", thus providing the firms with more space for professional judgment. Therefore, the firms are likely to use the professional judgment to reflect the real income and the structure of cost, which is beneficial for the development of firms especially for those with high technology and risk. However, while accounting standards give enterprises greater room for professional judgment, they may lead to earnings management and increase the confusion of divisional definition. In other words, there may be some artificial adjustments in the definition between government subsidies and operating income, which gives companies chances to do earnings management.

Government compensation plays an important role on firms in China since it symbolizes a sort of political connection. Some studies show that the improper government compensation disclosures may cause a negative influence on investors' judgement (Mao Lijuan, 2017). Other studies suggests that in Chinese securities market the investors always focus on the nominal earnings but do not care whether it is durable or not.

\subsection{State Hypotheses and Their Correspondence to Research Design}

The change may encourage managers or companies to do earnings management since the "operating profit" is served as 
an important index to evaluate the manager's performance. On the other hand, the investors might pay more attention on the "operating profits" which is used as an essential indicator to predict the companies' future profit growth. This is because the operating profit can better reflect a company's profitability than the net income which includes non-operating income. Hence, we assume that the revisions of government subsidy disclosure can exert a negative effect on the information content of earnings report. The mechanism behind this is that when one company's operating income incorporates a part of government subsidy, the investor have to exclude such kind of income from operating income for they want to focus on the company's inner growth and make right decisions of investing. So we hypothesize that this change will add more noise for evaluating the company's performance and thus reduce the earning quality. In order to test this hypothesis, we use the difference-in-difference model, dividing the samples into two groups: treated and control companies. The key assumption for the consistency of difference-to difference estimator is the paralleled trends assumption: in the absence of new revisions of accounting standards, treated and control firms should have paralleled trends in the outcome variable (ERC).

\section{Method}

In order to test our hypotheses, we establish a regression model using panel data. We divide this section into three parts: (1) Sampling procedures; (2) Sample Size, Power, and Precision; (3) Research Design.

\subsection{Sampling Procedures}

(1) Dependent variable - CAR

$C A R_{i t}$ is the 5-day market-adjusted stock return around the date around the yearly earnings announcement.

(2) Independent variable

$U E_{i t}$ is the unexpected earnings, which is calculated as the difference between actual yearly EPS and the previous yearly EPS. TREAT $T_{i t}$ is an indicator variable which equals one if firm i has government subsidy reflected in "other income" in earnings announcement, and zero if firm $\mathrm{i}$ only have government subsidy reflected in "Non-operating income" in earnings announcement. We focus only on 2015, 2016 and 2017 to keep the window as tight as possible in order to reduce the risk of capture other events. Thus, we identify $P O S T_{i t}$ as an indicator variable which equals zero in the year of 2015 and 2016, and one in the year of 2017. The rest of variables are served as control variables. The detailed definitions are listed as follows.

Table 1. Variable Definitions

\begin{tabular}{|c|c|}
\hline Variables & Definitions \\
\hline CAR & $\begin{array}{l}\text { A firm's 5-day market-adjusted stock return around the date around the yearly } \\
\text { earnings announcement. }\end{array}$ \\
\hline$U E$ & the difference between actual yearly EPS and the previous yearly EPS \\
\hline POST & $\begin{array}{l}\text { an indicator variable which equals zero in the year of } 2015 \text { and 2016, and one in } \\
\text { the year of } 2017\end{array}$ \\
\hline TREAT & $\begin{array}{l}\text { an indicator variable which equals one if firm i has government subsidy } \\
\text { reflected in "other income" in earnings announcement, and zero if firm i only } \\
\text { have government subsidy reflected in "Non-operating income" }\end{array}$ \\
\hline Control variables & Definitions \\
\hline LEV & Ratio of total debt to the book value of asset, as reported in Wind \\
\hline Market-to-book ratio & $\begin{array}{l}\text { Ratio of market value of equity to the book value of equity, both measured at } \\
\text { the end of the fiscal year, from Wind }\end{array}$ \\
\hline ROE & Return on equity \\
\hline Con & Represented by the shareholding ratio of the largest shareholder \\
\hline Beta & $\begin{array}{l}\text { The regression coefficient from regressing excess daily returns on a firm on } \\
\text { excess market returns over one year, ending on the fiscal year-end date }\end{array}$ \\
\hline size & Represented by logarithm of the company's total market value \\
\hline Nonlinear & Unexpected earnings multiplied by the absolute value of unexpected earnings \\
\hline Loss & $\begin{array}{l}\text { An } 0-1 \text { variable that equals one if the basic earnings per share excluding } \\
\text { extraordinary items is less than } 0 \text {, and } 0 \text { otherwise }\end{array}$ \\
\hline
\end{tabular}




\subsection{Sample Size, Power, and Precision}

Our samples include all Chinese A-share firms with required data on Wind, CSMAR. We select the sampling period from 2015 to 2017. We exclude the research samples of financial and insurance companies, because the financial structure of these companies is different from other companies. We exclude the firms whose whole period is ST or PT, so as to avoid the disturbance of single value of financial index of these companies which are under abnormal operation state to the total sample. We also exclude the samples whose some of the financial indexes are missing. In order to keep the results robust, we winsorize the continuous variables at $2 \%$ and $98 \%$ level. In the end, a total of 6080 sample observed values are observed.

Table 2 reports summery statistics for the main variables. The descriptive statistics for the full sample are generally similar to other studies using firms in Wind and CSMAR database. The arithmetical mean of CAR is 0.00352 , which means that Chinese A-share firms' CAR is positive on average. The arithmetical mean of unexpected return is 0.597 , which means there was a great change in the market's expectation under the revisions of accounting rules.

Table 2. Summary Statistics

\begin{tabular}{llllll}
\hline Variable & $\mathrm{N}$ & Mean & Std.Dev. & Min & Max \\
\hline UE & 6,080 & 0.597 & 0.311 & 0.0656 & 1.828 \\
beta & 8,743 & 1.063 & 0.455 & -0.766 & 13.79 \\
CAR & 7,795 & 0.00352 & 0.0792 & -1.542 & 0.606 \\
treat & 8,628 & 0.762 & 0.426 & 0 & 1 \\
lev & 8,984 & 0.412 & 0.205 & 0.0578 & 0.931 \\
roe & 8,972 & 0.0779 & 0.0997 & -0.358 & 0.370 \\
market-to-book ratio & 8,443 & 4.896 & 4.169 & 0.799 & 28.12 \\
size & 8,863 & 15.57 & 0.978 & 13.39 & 18.81 \\
con & 8,983 & 34.27 & 14.68 & 8.448 & 74.82 \\
beta & 6,749 & 1.278 & 0.336 & 0.378 & 2.346 \\
post & 8,993 & 0.371 & 0.483 & 0 & 1 \\
Nonlinear & 6,080 & 0.453 & 0.459 & 0.00430 & 3.341 \\
loss & 8,993 & 0.0786 & 0.269 & 0 & 1 \\
\hline
\end{tabular}

\subsection{Research Design}

Our identification strategy uses the adoption of new accounting standards. Because the new accounting rules were effective for companies after December 31, 2016, the timing of their adoption depended on companies' FY-end. We use the companies which not only have government subsidy but also put a part of them into "other income" in financial report as the treatment sample, as these firms were the first to be the subject of new rules. In contrast, we use firms whose government subsidy were all reflected in "non-operating income" as control samples, as these firms are not affected by the new accounting standards. Therefore, we can examine how investor's response to yearly earnings releases changed for treatment versus control firms from the year prior to 2016 to the subsequent year(2017), when treated firms were influenced but control firms were not.

In particular, we establish the following difference-to-difference design with data from 2015 to 2017 for treatment and control firms defined as above:

$$
\begin{gathered}
\text { CAR }_{i t}=\beta_{0}+\beta_{1} U E_{i t} * \text { POST }_{i t} * T_{R E A T}+\beta_{2} U E_{i t}+\beta_{3} T_{R E A T}+\beta_{4} \text { POST }_{i t}+\beta_{5} \text { TREAT }_{i t} * \text { POST }_{i t}+\beta_{6} U E_{i t} P_{\text {POST }}+ \\
\beta_{7} U E_{i t} \text { TREAT }_{i t}+\beta_{m} \text { Controls }+\beta_{n} U E_{i t} * \text { Controls }+\xi_{i t}(1)
\end{gathered}
$$

Our main variable of interest is $\beta_{1}$, the coefficient of $U E_{i t} * P O S T_{i t} * T R E A T_{i t}$, which captures the change in ERCs afor treated firms relative to control firms from the Pre (FY 2015 and FY 2016) to the Post (FY 2017).

\section{Results}

\subsection{Changes in ERC around the Revisions of Accounting Rules}

Our main analysis relies on a difference-to-difference design comparing the change in ERC around the adoption of new accounting standards for firms who are immediately subject to the rules (firms who had government subsidies in the 
item of "Other income" in earning announcement) and firms who are not subject to them. To do so, we estimate the regression (1). Table 3 reports the results of panel data with Fixed-effects and Random-Effects in order to test the robustness of the results.

To facilitate comparisons of previous studies, we first present the basic model without the indicator variables denoting the Post period and the treatment sample. The estimated coefficient of UE in the pooled sample is 0.0241 (using ordinary least squares, Column 3), generally in line with prior literature.

We then present our difference-to-difference analysis. Since it is a panel data, we use both random effects and fixed effects model to do analysis. In column (1) and column (2), we include the indicator variables for the post period and for the treatment sample and their interactions with each other and with UE, including firm characteristics and fixed effects and their interactions with UE. The coefficient on the variable of interest, $U E_{i t} * P O S T_{i t} * T R E A T_{i t}$ is negative and significant at the $10 \%$ level, in both column (1) and column (2). It means that the change of ERC is negative after the adoption of new accounting rules for treated firms. In other words, the investors' response to unexpected earnings decline after the adoption of new accounting standards because of the changing position of government subsidy.

Table 3. baseline regressions

\begin{tabular}{|c|c|c|c|}
\hline & (1) & $(2)$ & (3) \\
\hline & $\mathrm{RE}$ & $\mathrm{FE}$ & basic \\
\hline VARIABLES & CAR & CAR & CAR \\
\hline \multirow[t]{2}{*}{ UE*post*treat } & $-0.0338^{*}$ & $-0.0347^{*}$ & \\
\hline & $(0.0181)$ & $(0.0181)$ & \\
\hline \multirow[t]{2}{*}{ treat*post } & $0.0203^{*}$ & $0.0209 *$ & \\
\hline & $(0.0117)$ & $(0.0117)$ & \\
\hline \multirow[t]{2}{*}{ UE*post } & $0.0459 * * *$ & $0.0465 * * *$ & \\
\hline & $(0.0160)$ & $(0.0159)$ & \\
\hline \multirow[t]{2}{*}{ UE*treat } & 0.0119 & 0.0139 & \\
\hline & $(0.00955)$ & $(0.00950)$ & \\
\hline \multirow[t]{2}{*}{ UE*lev } & 0.00760 & 0.00746 & \\
\hline & $(0.0173)$ & $(0.0171)$ & \\
\hline \multirow[t]{2}{*}{$\mathrm{UE}^{*}$ lnasset } & $0.00287 * * *$ & $0.00298 * * *$ & \\
\hline & $(0.00101)$ & $(0.00100)$ & \\
\hline \multirow[t]{2}{*}{$\mathrm{UE}^{*} \mathrm{mb}$} & $0.000411 *$ & $0.000371 *$ & \\
\hline & $(0.000220)$ & $(0.000219)$ & \\
\hline \multirow[t]{2}{*}{$\mathrm{UE}^{*} \operatorname{con}$} & -0.0708 & -0.0586 & \\
\hline & $(0.0474)$ & $(0.0468)$ & \\
\hline \multirow[t]{2}{*}{$\mathrm{UE}^{*}$ roe } & $-0.0128 * * *$ & $-0.0130 * * *$ & \\
\hline & $(0.00408)$ & $(0.00404)$ & \\
\hline \multirow[t]{2}{*}{ UE*Inmarketvalue } & 0.00676 & 0.00922 & \\
\hline & $(0.0115)$ & $(0.0115)$ & \\
\hline UE*loss & $0.0510^{*}$ & $0.0562 *$ & \\
\hline (continued) & $(0.0295)$ & $(0.0293)$ & \\
\hline \multirow[t]{2}{*}{ loss*treat*post*UE } & -0.0107 & -0.0110 & \\
\hline & $(0.00958)$ & $(0.00953)$ & \\
\hline \multirow[t]{2}{*}{ treat } & -0.00389 & -0.00528 & \\
\hline & $(0.00596)$ & $(0.00591)$ & \\
\hline
\end{tabular}




\begin{tabular}{|c|c|c|c|}
\hline \multirow[t]{2}{*}{ post } & $-0.0291 * * *$ & $-0.0283 * * *$ & \\
\hline & $(0.0103)$ & $(0.0103)$ & \\
\hline \multirow[t]{2}{*}{ UE } & $0.203 * * *$ & $0.201 * * *$ & $0.0241 * *$ \\
\hline & $(0.0683)$ & $(0.0677)$ & $(0.0103)$ \\
\hline \multirow[t]{2}{*}{ lev } & -0.00199 & -0.00574 & -0.00326 \\
\hline & $(0.0120)$ & $(0.0114)$ & $(0.00521)$ \\
\hline \multirow[t]{2}{*}{$\mathrm{mb}$} & $-0.00325^{* * *}$ & $-0.00299 * * *$ & $-0.00115^{* * *}$ \\
\hline & $(0.000708)$ & $(0.000694)$ & $(0.000298)$ \\
\hline \multirow[t]{2}{*}{ roeb } & $0.0693 * *$ & $0.0635^{*}$ & 0.0163 \\
\hline & $(0.0351)$ & $(0.0344)$ & $(0.0170)$ \\
\hline \multirow[t]{2}{*}{ con } & $-0.000340^{* *}$ & $-0.000338^{* * *}$ & -0.000107 \\
\hline & $(0.000148)$ & $(0.000146)$ & $(6.88 \mathrm{e}-05)$ \\
\hline \multirow[t]{2}{*}{ beta } & -0.00713 & -0.00684 & -0.00122 \\
\hline & $(0.00795)$ & $(0.00786)$ & $(0.00349)$ \\
\hline \multirow[t]{2}{*}{ lnmarketvalue } & $0.00437 *$ & $0.00531^{* *}$ & -0.00117 \\
\hline & $(0.00261)$ & $(0.00257)$ & $(0.00122)$ \\
\hline \multirow[t]{2}{*}{ Nonlinear } & $-0.0332 * * *$ & $-0.0333 * * *$ & $-0.0159 * *$ \\
\hline & $(0.0102)$ & $(0.0101)$ & $(0.00767)$ \\
\hline \multirow[t]{2}{*}{ loss } & $-0.0563^{*}$ & $-0.0614 *$ & 0.0101 \\
\hline & $(0.0341)$ & $(0.0339)$ & $(0.00706)$ \\
\hline Industrial & control & control & control \\
\hline \multirow[t]{2}{*}{ cons } & -0.0287 & -0.0538 & 0.0282 \\
\hline & $(0.0513)$ & $(0.0434)$ & $(0.0206)$ \\
\hline observations & 5,110 & 5,110 & 5,261 \\
\hline
\end{tabular}

Standard errors in parentheses

$* * * \mathrm{p}<0.01, * * \mathrm{p}<0.05, * \mathrm{p}<0.1$

\subsection{Robustness Test}

Since the target firms' asset size, stock liquidity, growth rate, profitability or other factors have obvious characteristics, in order to avoid the impact of these factors on the research results, we use entropy balancing, a quasi-matching technique which reweights control observations to obtain better matching with the treatment observations in order to screen out the corresponding control samples. First, we use the financial information at the time when the new accounting standard begun to be adopted to build logit model. We add all control variables in model (1) to the regression to ensure there are no significant differences between treatment firms and control firms. Then, based on the calculated score, we match the treatment firms with control firms one by one. Table 4 reports the results by using PSM. We can see that the coefficient of UE* post*treat is still significantly negative $(-0.0339$ in RE model and -0.037 in FE model), which means the result is robust and the revisions of accounting standards in government subsidies exert a negative influence on the earnings quality. 
Table 4. Entropy balancing results

\begin{tabular}{|c|c|c|c|}
\hline & (1) & (2) & (3) \\
\hline & $\mathrm{RE}$ & $\mathrm{FE}$ & basic \\
\hline VARIABLES & CAR & CAR & CAR \\
\hline \multirow[t]{2}{*}{ UE*post*treat } & $-0.0339 *$ & $-0.0370 * *$ & \\
\hline & $(0.0185)$ & $(0.0185)$ & \\
\hline \multirow[t]{2}{*}{ treat*post } & $0.0212 *$ & $0.0230 *$ & \\
\hline & $(0.0119)$ & $(0.0119)$ & \\
\hline \multirow[t]{2}{*}{ UE*post } & $0.0448 * * *$ & $0.0488 * * *$ & \\
\hline & $(0.0155)$ & $(0.0155)$ & \\
\hline \multirow[t]{2}{*}{$\mathrm{UE}^{*}$ treat } & 0.0146 & $0.0173^{*}$ & \\
\hline & $(0.00972)$ & $(0.00971)$ & \\
\hline \multirow[t]{2}{*}{$\mathrm{UE}^{*}$ lev } & -0.000363 & 0.00119 & \\
\hline & $(0.0196)$ & $(0.0195)$ & \\
\hline \multirow[t]{2}{*}{$\mathrm{UE}^{*}$ lnasset } & $0.00315 * * *$ & $0.00352 * * *$ & \\
\hline & $(0.00119)$ & $(0.00118)$ & \\
\hline \multirow[t]{2}{*}{$\mathrm{UE}^{*} \mathrm{mb}$} & $0.000507 * *$ & $0.000448 *$ & \\
\hline & $(0.000250)$ & $(0.000250)$ & \\
\hline \multirow[t]{2}{*}{$\mathrm{UE}^{*} \operatorname{con}$} & -0.0421 & -0.0313 & \\
\hline & $(0.0540)$ & $(0.0535)$ & \\
\hline \multirow[t]{2}{*}{$\mathrm{UE}^{*}$ roe } & $-0.0137 * * *$ & $-0.0135 * * *$ & \\
\hline & $(0.00472)$ & $(0.00469)$ & \\
\hline \multirow[t]{2}{*}{ UE*Inmarketvalue } & 0.000594 & 0.00353 & \\
\hline & $(0.0137)$ & $(0.0137)$ & \\
\hline \multirow[t]{2}{*}{ UE*loss } & $0.0781 * *$ & $0.0845^{* *}$ & \\
\hline & $(0.0357)$ & $(0.0356)$ & \\
\hline \multirow[t]{2}{*}{ loss*treat*post*UE } & -0.0209 & -0.0206 & \\
\hline & $(0.0136)$ & $(0.0135)$ & \\
\hline \multirow[t]{2}{*}{ treat } & -0.00518 & -0.00650 & \\
\hline & $(0.00605)$ & $(0.00606)$ & \\
\hline \multirow[t]{2}{*}{ post } & $-0.0288 * * *$ & $-0.0293 * * *$ & \\
\hline & $(0.0100)$ & (0.00999) & \\
\hline \multirow[t]{2}{*}{ UE } & $0.226 * * *$ & $0.218 * * *$ & $0.0379 * * *$ \\
\hline & $(0.0790)$ & $(0.0785)$ & $(0.0123)$ \\
\hline \multirow[t]{2}{*}{ lev } & 0.00424 & -0.00417 & -0.00448 \\
\hline & $(0.0132)$ & $(0.0126)$ & $(0.00604)$ \\
\hline \multirow[t]{2}{*}{$\mathrm{mb}$} & $-0.00308 * * *$ & $-0.00284 * * *$ & $-0.000634 *$ \\
\hline & $(0.000835)$ & $(0.000821)$ & $(0.000380)$ \\
\hline \multirow[t]{2}{*}{ roeb } & $0.0753 *$ & $0.0730^{*}$ & $0.0384^{*}$ \\
\hline & $(0.0401)$ & $(0.0395)$ & $(0.0202)$ \\
\hline con & $-0.000366 * *$ & $-0.000395 * *$ & $-0.000144 *$ \\
\hline
\end{tabular}




\begin{tabular}{llll} 
& $(0.000163)$ & $(0.000162)$ & $(7.94 \mathrm{e}-05)$ \\
beta & -0.00802 & -0.00671 & -0.00585 \\
& $(0.00916)$ & $(0.00907)$ & $(0.00422)$ \\
lnmarketvalue & 0.00479 & $0.00572^{* *}$ & -0.00104 \\
& $(0.00293)$ & $(0.00291)$ & $(0.00145)$ \\
Nonlinear & $-0.0359^{* * *}$ & $-0.0379^{* * *}$ & $-0.0232^{* *}$ \\
& $(0.0115)$ & $(0.0113)$ & $(0.00938)$ \\
loss & $-0.0878^{* *}$ & $-0.0936^{* *}$ & 0.00757 \\
Constant & $(0.0417)$ & $(0.0416)$ & $(0.00848)$ \\
& -0.0655 & -0.0629 & 0.0245 \\
& $(0.0626)$ & $(0.0494)$ & $(0.0246)$ \\
Observations & & & \\
\hline
\end{tabular}

Standard errors in parentheses

$* * * \mathrm{p}<0.01, * * \mathrm{p}<0.05, * \mathrm{p}<0.1$

\section{Discussion \& Conclusion}

We empirically examine the hypotheses that information of content of earnings report, which is quantified by the earnings response coefficient (ERC), decreases when a part of government subsidy is reflected in the items of "Other income" in earnings report. That means there will be more noise in earnings report for investors to make decisions of investing. Under the old accounting rules, all the government subsidies are reflected in the item of "non-operating income" as this kind of source of income comes from the outside of firm. However, due to the adoption of new accounting rules, the information of content of earnings report declines. One explanation for this decline is that investors always pay more attention on the items of "operating income" and "operating profits" since these two items reflect the companies' interior profitability. According to MM, investors often make some adjustments on the reported earnings to better their prediction about the value of target firms. Thus, it is somewhat difficult for them to decide in what way they should adjust the government subsidies in order to reflect the firm's true profitability and growth. The prerequisite for this is that the security market is efficient. Although some studies in the past twenty decades suggested that there are some phenomenon of "function locking" in China's security markets, but now the security markets are becoming more and more efficient due to the development of financial market and economic. The main purpose of shareholders is to earn more profit, so they sometimes care more about whether a firm has an expected growth or not when selecting stocks to invest. In order to achieve their goal, they have to establish some principal using the items reflected in earnings report as indicators to help them judge. Thus, with a part of government subsidies under the item of "Operating profits", the investors will not completely trust the company's interior profitability because the operating profits a firm earn cannot better reflect its true profitability. Due to the existence of accounting fixation, investors may have cognitive bias to analyze the firms' earnings report. Thus, they response less to unexpected earnings because of too much noise. An alternative explanation is that managers might have some incentives to increase or reduce the total amount of operating profit to achieve some goals, so it is possible that they make the government subsidy reflect on the item of "Other income" as much as possible even though they are not completely required to be reflected in "Other income", which in turn reduce the information content of earnings report.

In addition to contributing to the research of ERC and literature on the government compensation disclosures, our study suggests that new accounting rules in China should do some further revisions to increase the information content of earnings report. As is known, one of the main purpose of making earnings report is to help the investors to make right decisions. Therefore, the policy makers should make accounting rules considering different factors as much as possible. Although there is a tendency of convergence between Chinese accounting standards and International Financial Reporting Standards (IFRS), the Chinese accounting rules should be revised based on the real situations. Thus, this research suggests that policy makers should issue more guidelines to curb the artificial adjustments in the definition of government subsidies and operating income. This will prevent firms from listing the non-operating income that originally belonged to government subsidies as operating income. Although being consistent with International Financial Standards can bring too many benefits, we are supposed to make some special revisions according to some special situations since the thoughts and behaviors of investors in different countries have some difference. Sometimes 
it is possible that other countries' accounting standards cannot apply to our own country's capital market well. Making some special guidelines might reduce the level of earnings management and increase the earnings quality. Thus, it is better to take some factors like investors' thoughts and behaviors or something into consideration when making accounting standards.

\section{References}

Beaver, W. H. (1968). The information content of annual earnings announcements. Journal of Accounting Research, 67-92. https://doi.org/10.2307/2490070

Dearman, D. T., \& Shields, M. D. (2005). Avoiding accounting fixation: Determinants of cognitive adaptation to differences in accounting method. Contemporary Accounting Research, 22(2), 351-384. https://doi.org/10.1506/RQ40-UR50-5CRL-YU8A

Dechow, P. M., Sloan, R. G., \& Sweeney, A. P. (1996). Causes and consequences of earnings manipulation: An analysis of firms subject to enforcement actions by the SEC. Contemporary Accounting Research, 13(1), 1-36. https://doi.org/10.1111/j.1911-3846.1996.tb00489.x

Ewert, R., \& Wagenhofer, A. (2005). Economic effects of tightening accounting standards to restrict earnings management. The Accounting Review, 80(4), 1101-1124. https://doi.org/10.2308/accr.2005.80.4.1101

Goncharov, I., \& Zimmermann, J. (2006). Do accounting standards influence the level of earnings management? Evidence from Germany. Evidence from Germany (December 2006).

Jeanjean, T., \& Stolowy, H. (2008). Do accounting standards matter? An exploratory analysis of earnings management before and after IFRS adoption. Journal of Accounting and Public Policy, 27(6), 480-494. https://doi.org/10.1016/j.jaccpubpol.2008.09.008

Landsman, W. R., Maydew, E. L., \& Thornock, J. R. (2012). The information content of annual earnings announcements and mandatory adoption of IFRS. Journal of Accounting and Economics, 53(1-2), 34-54. https://doi.org/10.1016/j.jacceco.2011.04.002

Mao Lijuan. (0). Analysis of the status quo and countermeasures of government subsidy information disclosure. Finance Communications, No.699(07), 66-69.

Schipper, K., \& Vincent, L. (2003). Earnings quality. Accounting Horizons, 17, 97-110. https://doi.org/10.2308/acch.2003.17.s-1.97

Watts, R. L., \& Zimmerman, J. L. (1990). Positive accounting theory: a ten year perspective. Accounting Review, 131-156.

\section{Copyrights}

Copyright for this article is retained by the author(s), with first publication rights granted to the journal.

This is an open-access article distributed under the terms and conditions of the Creative Commons Attribution license which permits unrestricted use, distribution, and reproduction in any medium, provided the original work is properly cited. 